\title{
1 Risk factors associated with increased mortality of farmed Pacific oysters in Ireland
}

$2 \quad$ during 2011

3

4 Tracy A. Clegg ${ }^{a}$, Teresa Morrissey ${ }^{b}$, Fiona Geoghegan $^{\mathrm{b}}$, S. Wayne Martin ${ }^{\mathrm{c}}$, Kieran Lyons ${ }^{\mathrm{b}}$, 5 Seán Ashe ${ }^{\mathrm{d}}$, Simon J. More ${ }^{\mathrm{a}}$

7 a. UCD Centre for Veterinary Epidemiology and Risk Analysis, University College Dublin, 8 Belfield, Dublin 4, Ireland

9 b. Marine Institute, Rinville, Oranmore, Co. Galway, Ireland

10 c. Department of Population Medicine, Ontario Veterinary College, University of Guelph,

11 Guelph, Ontario N1G 2W1, Canada

12 d. Department of Agriculture, Food and the Marine, Kildare Street, Dublin 2, Ireland

14 Corresponding author: Tracy Clegg, ph +3531716 6142, fax +3531 7166147

15 email: tracy.clegg@ucd.ie

\section{Abstract}

The Pacific oyster, Crassostrea gigas, plays a significant role in the aquaculture industry in Ireland. Episodes of increased mortality in C. gigas have been described in many countries, and in Ireland since 2008. The cause of mortality events in C. gigas spat and larvae is suspected to be multifactorial, with Ostreid herpesvirus 1 (OsHV-1, in particular OsHV-1 $\mu v a r)$ considered a necessary, but not sufficient, cause. The objectives of the current study were to describe mortality events that occurred in C. gigas in Ireland during the summer of 2011 and to identify any associated environmental, husbandry and oyster endogenous factors. 
26 A prospective cohort study was conducted during 2010 to 2012, involving 80 study batches,

27 located at 24 sites within 17 bays. All 17 bays had previously tested positive for OsHV1-

$28 \mu$ var. All study farmers were initially surveyed to gather relevant data on each study batch,

29 which was then tracked from placement in the bay to first grading. The outcome of interest

30 was cumulative batch-level mortality (\%). Environmental data at high and low mortality sites

31 were compared, and a risk factor analysis, using a multiple linear regression mixed effects

32 model, was conducted. Cumulative batch mortality ranged from $2 \%$ to $100 \%$ (median $=16 \%$,

33 interquartile range: $10 \%$ - 34\%). The final multivariable risk factor model indicated that

34 batches imported from French hatcheries had significantly lower mortalities than non-French

35 hatcheries; sites which tested negative for OsHV-1 $\mu$ var during the study had significantly

36 lower mortalities than sites which tested positive and mortalities increased with temperature

37 until a peak was reached. There were several differences between the seed stocks from

38 French and non-French hatcheries, including prior OsHV-1 $\mu$ var exposure and ploidy. A

39 range of risk factors relating to farm management were also considered, but were not found

40 significant. The relative importance of prior OsHV-1 $\mu$ var infection and ploidy will become

41 clearer with ongoing selection towards OsHV-1 $\mu$ var resistant oysters. Work is currently

42 underway in Ireland to investigate these factors further, by tracking seed from various

43 hatchery sources which were put to sea in 2012 under similar husbandry and environmental

44 conditions.

45

46 Key words: oysters, Crassostrea gigas, mortality, Ireland, risk factors

47

48 1. Introduction

49 
50 The Pacific oyster, Crassostrea gigas, plays a significant role in the aquaculture industry in

51 Ireland, both in terms of volume and value, with an annual production of over 7,000 metric tonnes (Bord Iascaigh Mhara (BIM) / the Irish Sea Fisheries Board, personal communication). With a current value of €28-30 million per year, C. gigas accounts for approximately $20 \%$ by volume of overall shellfish produced in Ireland (BIM, personal communication). The main method of cultivation for Pacific oysters used in Ireland is bag and trestle cultivation, which is an off-bottom culture method. This cultivation method allows the oysters to be placed in mesh bags on metal framed structures called trestles in the intertidal zone, which allows access to the stock during low tide (Tidwell et al., 2012). Over half of all current licensed aquaculture producers in Ireland are oyster farmers, with C. gigas being grown in 44 bays all around the coast. C. gigas seed is predominantly sourced from hatcheries / nurseries or harvested wild seed, which is imported mainly from France and to a much smaller extent from the UK and the Channel Islands. The main export market for

63 Pacific oysters is France, although there is also a growing market in Asia.

Since the 1950 s, episodes of increased mortality in C. gigas have been described globally in all areas of production. In Europe, severe mortality events in cultured Pacific oyster were observed during the summers of 2008 and 2009 (Dégremont et al., 2013). These events have been grouped by life stage into summer mortality in adults, mortality in spat and hatcheryrelated mortality (European Food Safety Authority, 2010). Mortality in spat and larvae at hatcheries have been associated with detection of ostreid herpesvirus 1 (OsHV-1), a virus also associated with mortality in other farmed bivalves, including the European flat oyster (Ostrea edulis), scallop (Pecten maximus) and the Manila clam (Ruditapes philippinarum)

73 (Renault et al., 2001; Arzul et al., 2002; Batista et al., 2007). In 2000, OsHV-1var, a variant strain of OsHV-1, was identified in French hatcheries (Arzul et al., 2001a,b). Although 
75 OsHV-1var presents several modifications in the $\mathrm{C}$ region of the genome, where the most 76 significant modifications in relation to OsHV-1 occur, and a $2.8 \mathrm{~kb}$ deletion, OsHV-1 and

77 OsHV-1var are considered representative of a single viral species as the differences between

78 the two genotypes were not great enough to establish a separate viral species (Arzul et al.,

79 2001b). In 2008, the emergence of a third strain was described, OsHV-1 $\mu$ var, in association

80 with abnormal mortality in C. gigas in France (Segarra et al., 2010; Dégremont et al., 2013).

81 It has since been shown that mortality in C. gigas spat can be induced following experimental

82 infection with OsHV-1 $\mu$ var (Schikorski et al., 2011). Further, mortality can be induced

83 following horizontal transmission of infection from unselected asymptomatic adult to

84 juvenile $C$. gigas (Dégremont et al., 2013). Since 2009, OsHV-1 $\mu$ var has been the

85 predominant herpes virus strain during mortality events (European Food Safety Authority,

86 2010). It is now believed that the cause of mortality events in C. gigas spat and larvae is

87 multifactorial, with OsHV-1 infection (with OsHV-1 $\mu$ var now predominating) a necessary

88 but not sufficient cause (Samain and McCombie, 2010). Other suspected risk factors include

89 an increase or a sudden change in the temperature, husbandry practices such as introduction

90 of possibly infected spat, and the movement and mixing of populations and age groups

91 (European Food Safety Authority, 2010; Garcia et al., 2011). The European Food Safety

92 Authority (2010) also noted that no outbreaks had been reported when the water temperature

93 was below $16^{\circ} \mathrm{C}$.

95 In Ireland, mortality events in C. gigas have been reported for some years (Malham et al., 96 2009), but linked, since 2008, to the presence of OsHV-1 $\mu$ var (D. Cheslett, personal

97 communication). In that year, reports of mortality in Pacific oysters were received from three

98 oyster producing bays, and the presence of the OsHV-1 $\mu$ var was confirmed in all three bays

99 by PCR and sequence analysis of the amplicon (European Food Safety Authority, 2010). In 
100

101

102

103

104

105

106

107

108

109

110

111

112

113

114

115

116

117

118

119

120

121

122

123

124

2009, extensive mortality and the presence of OsHV-1 $\mu$ var were reported from 15 oyster production areas, peaking in July with an average batch mortality of $37 \%$ and with mortality occurring, on average, over an 18 day period (Peeler et al., 2012). Although few clear associations between mortality and management factors were identified, the age of oysters when first infected with OsHV-1 $\mu$ var, the condition of the oysters, temperature, and other environmental factors each appeared important (Peeler et al., 2012). European Union legislation was subsequently introduced to prevent the spread of the virus to unaffected areas in Ireland and the United Kingdom, whilst still allowing trade to continue between infected areas (European Community, 2010), but noting that there was no realistic prospect of eliminating the virus (Peeler et al., 2010). OsHV-1 $\mu$ var related mortality has continued in Ireland each summer since the initial detection of OsHV-1 $\mu$ var in 2008, both in bays previously infected with this virus and coincident with spread of infection to new bays.

The objectives of the current study were to describe any mortality events that occurred in $C$. gigas in Ireland during the summer of 2011 and to identify any associated environmental, husbandry and endogenous oyster factors, thereby providing information which could assist oyster farmers in minimising batch mortality in endemically affected areas.

\section{Materials and methods}

\subsection{Study design and population}

A prospective cohort study was conducted during 2010 to 2012, from the time of first batch immersion (03 August 2010), when oysters were two mm in size. The oysters were followed until the date of last batch grading before data analysis, in spring/summer 2012 (12 April 
125

126

127

128

129

130

131

132

133

134

135

136

137

138

139

140

141

142

143

144

145

146

147

148

2012), where oysters had been immersed for up to 18 months (subsequently termed the study period). The oyster batch was the unit of interest, and was defined as a variable number of oysters of similar size, originating from one hatchery, placed at a particular site within a bay at one point in time. All 405 batches of farmed oysters that were in the sea in Ireland during 2011 were considered for inclusion in the study. Farms were selected for logistical reasons, such as the accessibility of stock to allow for frequent monitoring and the capacity to monitor individual batches among the stock throughout the season. From the selected farms batches were chosen in order to include batches from different hatcheries, ploidy status and immersion date within each bay.

The number of batches required for the study was estimated, based on a confidence interval of $95 \%$ (alpha $=0.05)$, a power of $80 \%$ and assuming a mortality of $43 \%$ amongst batches in OsHV-1 positive bays and 12\% in OsHV-1 negative bays (based on reported site-level mortality from the 2009 Irish survey (Peeler et al., 2010); data as presented for OsHV1 positive bays and as estimated for OsHV-1 negative bays). The initial sample size was calculated using the following formula to detect a difference between two proportions (Dohoo et al., 2009) :

$\mathrm{n}=\left[\mathrm{Z}_{\alpha} \sqrt{ }(2 \mathrm{pq})-\mathrm{Z}_{\beta} \sqrt{ }\left(\left(\mathrm{p}_{1} \mathrm{q}_{1}\right)+\left(\mathrm{p}_{2} \mathrm{q}_{2}\right)\right)\right]^{2} /\left(\mathrm{p}_{1}-\mathrm{p}_{2}\right)^{2}$

Where: $Z_{\alpha}=1.96$, the value required for a confidence of $95 \%, Z_{\beta}=-0.84$ the value required for a power of $80 \%, \mathrm{p}_{1}=$ estimate of lower proportion of disease, $\mathrm{p}_{2}=$ estimate of higher proportion of disease, $\mathrm{q}_{1}=1-\mathrm{p}_{1}, \mathrm{q}_{2}=1-\mathrm{p}_{2}, \mathrm{p}=\left(\mathrm{p}_{1}+\mathrm{p}_{2}\right) / 2$ and $\mathrm{q}=1-\mathrm{p}$.

The sample size was further adjusted to account for other confounders. Assuming other confounders were not strong confounders the sample size was increased by $15 \%$ (Dohoo et al., 2009, page 50). Clustering within farms was accounted for using the following formula:

$\mathrm{n}^{\prime}=\mathrm{n}(1+\rho(\mathrm{m}-1))$ 
149 Where: $\rho$ is the intra-cluster correlation coefficient, assumed to be 0.5 and $\mathrm{m}$ is the average

150 number of batches of oysters per farm, assumed to be 3 . In total, the aim of the study was to 151 sample around 80 batches.

152

153

2.2 Data collection

154

155 An initial survey of all study farmers was conducted to gather relevant data on each study

156 batch, and to provide a framework for data collection at batch-level throughout the study

157 period. The survey was administered in a joint effort by BIM regional officers and the Fish

158 Health Unit of the Marine Institute (MI). Each study batch was tracked throughout the study

159 period. To achieve this, BIM Regional Officers made regular visits to survey the batches and

160 collect data on batch identification, risk factors of interest, batch mortality data, splitting,

161 grading and handling frequency. For any batch where mortality occurred, details of the

162 mortality event were recorded (i.e. start and finish date of the mortality episode, estimated

163 percentage mortality in the batch, any predisposing factors). Data were recorded on

164 specifically designed survey forms which were submitted to the MI and entered into a

165 Microsoft Access database. Data collection sheets are available in Appendix A.

166

167 Samples of the stock (30 animals from one batch in each bay; Table 1) were tested for the

168 presence of OsHV-1 in the Fish Health Unit laboratory at the Marine Institute. Cell lysis and

169 nucleic acid extraction was carried out using QIAamp DNA Mini Kit (Qiagen) using Qiagen

170 QIAcube, according to the manufacturer's instructions. DNA extracts obtained were

171 subjected to an initial screening process for the presence of OsHV-1 using real-time PCR

172 analysis based on a Sybr Green chemistry with $\mathrm{C} 9 / \mathrm{C} 10$ primer set targeting the $\mathrm{C}$ region of

173 the genome (Pepin et al., 2008). Confirmatory testing for OsHV-1 $\mu$ var was carried using 
174

175

176

177

178

179

180

181

182

183

184

185

186

187

188

189

190

191

192

193

194

195

196

197

198

nested PCR where subsamples of real-time positive PCR products were analysed using nested conventional PCR, using C2/C6 primers (Arzul et al., 2002) in the first round of conventional PCR, and internal primer set F-int/R-int, with a 514bp expected product size in the second round of conventional PCR, using PCR conditions (unpublished, D. Stone, CEFAS, UK).

A total of 55 data loggers, at least one per bay, were deployed to obtain environmental data.

These were deployed in May 2011 on a small number of sites, due to availability of equipment, with further deployments made in early June 2011 on the remaining sites. Five different types of data loggers (two large types and three small types) were deployed, each recording a number of different parameters. The smaller data loggers were deployed attached to the bags in the batch of interest, whereas the larger data loggers were deployed alongside the trestles which held the batch of interest. These data loggers were programmed to record environmental parameters every hour for the duration of the deployment, with regular maintenance and calibration on a monthly basis. An illustration of the location of data loggers at Dungarvan bay is shown in Figure 1.

$<$ Figure 1 here $>$

2.3 Descriptive analysis of temperature at high mortality sites where start date of mortality recorded

A high mortality site was defined as a site where 1 or more batches experienced a cumulative batch-level mortality $>34 \%$ (being the upper mortality quartile) during the study period. A low mortality site was defined as a site where no batches experienced a cumulative batch mortality $>34 \%$. At all high mortality sites with available data (reported start date of 
199

200

201

202

203

204

205

206

207

208

209

210

211

212

213

214

215

216

217

218

219

220

221

222

223

mortality event and temperature data during the 30 preceding days), the median temperature within the previous 7 and 30 days prior to the recorded start of mortality were reported. At all low mortality sites, the median temperature during the same time periods as each of the high mortality batches was also reported, for comparison.

At all high mortality sites with available data, a visual assessment of temperature changes was made during the period when mortality events were first recorded. A low-pass filter using Matlab (MathWorks, Natick, MA, USA), was used to remove the tidal, diurnal and other high frequency signals from the temperature time series, in order to assess the overall trend in temperature during the period when mortality occurred, particularly with respect to a $16^{\circ} \mathrm{C}$ threshold.

\subsection{Linear Mixed model analysis}

The cumulative batch-level mortality from placement to first grading was the outcome of interest. The independent variables, for consideration during the risk factor analysis, are presented in Table 1.

$<$ Table 1 here $>$

Due to the highly skewed nature of the mortality data, the natural logarithm was used to transform these to a normal distribution. In addition the appropriate transformation of the outcome was assessed based on the residuals from the final model, comparing the profile likelihood ratio to identify the optimal box-cox transformation (Dohoo et al., 2009). 
224 A mixed linear regression model of cumulative batch-level mortality was developed using

225 SAS version 9.1.3 (SAS Institute Inc., 2003). A univariable screening approach was used,

226 where all variables with $\mathrm{p}<0.2$ at the univariable stage became candidates for the

227 multivariable model. The need for a 'farm' random effect was tested within the mixed model,

228 using a likelihood ratio test (Dohoo et al., 2009), to account for clustering of batches within

229 farms. A backward selection procedure was used to eliminate terms from the model based on

230 an F-test $(\mathrm{p}>0.05)$. The relationship between continuous predictors and the outcome was

231 examined using plots of the continuous predictors against the logarithm of batch mortality.

232 Where no obvious linear or polynomial relationship was observed, continuous predictors

233 were categorised into four groups based on the corresponding quartiles. Variables that were

234 not significant at the univariable screening stage were added to the final model and tested

235 using an F-test $(\mathrm{p}<0.05)$. In addition, variables that, when combined, represent an underlying

236 effect were tested in combination as described by Cohen et al. (2003) by adding the combined

237 variables to the final model. For example, the variables: 'number of times bags were turned'

238 and 'handling at grading' when combined were considered to represent a 'bag handling' effect.

239 The correlation between covariates was evaluated using a chi-square test between nominal

240 variables and kendall's tau-b assessment of correlation between continuous variables. Plots of

241 studentised residuals from the final model and influence plots were examined to identify lack

242 of fit or any outliers from the final model.

\section{3. Results}

245

$246 \quad 3.1$ Study population

247 
248 A total of 80 study batches, from 28 farms, located at 24 sites within 17 infected bays were

249 included in the study (Figure 2). The batches contained between 10 and 4,650 bags of oysters

250 with a median number of 215 bags per batch. The median number of oysters per bag as at the

251 end of May 2011 was 2,000; this varied between 210 to 15,000 oysters per bag between

252 batches. Cumulative batch mortality ranged from $2 \%$ to $100 \%$, with a median batch mortality

253 of $16 \%$ and an interquartile range of between $10 \%$ and $34 \%$ (Figures 2 and 3 ).

$<$ Figure 2 here $>$

256

$<$ Figure 3 here $>$

257

258

3.2 Descriptive analysis of temperature at high mortality sites where start date of mortality

recorded

There were 14 high mortality sites (mortality $>34 \%$ ), with a total of 20 high mortality batches

262 (out of 52 batches at these sites), and 10 low mortality sites (no batches experienced a cumulative batch mortality $>34 \%$ ), with a total of 28 batches. Of the high mortality sites, 10

264 sites had a recorded start date for mortalities, however, three of these sites had missing

265 temperature data (three sites in Ballymacoda, Bannow and Lough Foyle bays). The median temperature within 7 and 30 days of the reported start of mortality at the seven high mortality

267 sites with a recorded start date of mortality and relevant temperature data is shown in Table 2.

268 The median temperatures at the 10 low mortality sites during the same time periods as each 269 of the high mortality sites are also presented in Table 2. The interquartile range for the high 270 mortality sites overlapped the interquartile range for the low mortality sites during the 7 and

27130 days time intervals, with the exception of the site at Lough Swilly, indicating that there 
272 was little difference in temperature between the low and high mortality sites prior to the start

273 of mortalities.

274

$275<$ Table 2 here $>$

276

277 A visual assessment of temperature data during the reported start of mortality at the seven

278 high mortality sites with a recorded start date for mortalities and temperature data prior to the

279 start of mortalities is presented in Appendix B. At four sites (Achill Sound, Dungloe,

280 Trawbreaga Bay and Woodstown Strand), an increase in temperature over $16^{\circ} \mathrm{C}$ coincided

281 with the time period when mortality events were first reported; at one site (Sherkin), no visual

282 association was observed; and at two sites (Clew Bay, Lough Swilly), a substantial change in

283 temperature, in this case a decline followed by an increase, was coincident with the time

284 period when mortality was first reported.

285

286

3.3 Linear mixed effects regression model

287

288 All predictors with a p-value in the univariable analysis of $<0.2$ were considered in the initial

289 linear mixed effects regression model (Table 3). The risk factors entered into the initial model

290 were: size, ploidy, OsHV-1 $\mu$ var bay status, hatchery and the maximum summer temperature.

291 The remaining significant variables after the backward selection process were: OsHV-1 $\mu$ var

292 bay status and hatchery. Variables that were not significant at the univariable stage $(\mathrm{p}>0.2)$,

293 and combined variables representing an underlying effect were added to the model, however,

294 none were significant. The studentised residuals were plotted against each of the variables not

295 in the current model using a Loess smooth to identify any potential relationships. The Loess

296 plot against 'maximum summer temperature' suggested a possible quadratic relationship. A 
297

298

299

300

301

302

303

304

305

306

307

308

309

310

311

312

313

314

315

316

317

318

319

320

321

quadratic term of the 'maximum summer temperature', after centring the variable to account for correlation between the original value and the quadratic term (Dohoo et al., 2009), was significant when added to the model (Table 4). Residuals from the final model indicated no significant lack of fit and no significant outliers. The appropriate transformation of the outcome variable (cumulative batch-level mortality), based on residuals from the initial model (i.e. containing hatchery and OsHV-1 $\mu$ var bay status) and comparing the raw mortality, natural logarithm transformation, arcsine transformation and box-cox transformations were assessed. The natural logarithm transformation was deemed as the most appropriate based on residuals and assessment of box-cox transformations and comparing the profile log-likelihood (Dohoo et al., 2009). The 'farm' random effect was significant (likelihood ratio test: $\mathrm{p}=0.023$ ) and $38 \%$ of the variance was between farms and $62 \%$ within farms.

$<$ Table 3 here $>$

A plot of the best unbiased linear estimates of mortality against the 'maximum summer temperature' is shown in Figure 4, indicating an increase in mortality which appears to level off after a temperature peak was reached. The final model also showed that batches imported from French hatcheries 1, 2, 4 and 5 had significantly lower mortalities than batches imported from Non-French hatchery 2. Non-French hatchery 1 mortalities were not significantly different to those from Non-French hatchery 2. Further, batches grown in bays which tested OsHV-1 $\mu$ var negative during the study had significantly lower mortalities than batches grown in bays which had tested positive.

$<$ Table 4 here $>$ 
$<$ Figure 4 here $>$

323

324

4. Discussion

325

326

327

328

329

330

331

332

333

334

335

336

337

338

339

We noted a strong association between hatchery of origin and mortality, with seed imported from French hatcheries experiencing markedly lower mortality compared with seed imported from non-French hatcheries, when placed in bays which were historically infected with

OsHV-1 $\mu$ var. As illustrated in Table 3, the median cumulative mortality of batches from French hatcheries varied between 7 and 25\%, and from non-French hatcheries between 76 and $86 \%$. There are several differences between these two seed stocks, which may at least partly explain this result. The first relates to prior OsHV-1 $\mu$ var exposure. This virus is endemic in France (Pernet et al., 2012). Therefore, prior exposure to this virus, either of the seed itself or of the related broodstock, can be assumed. In contrast, the non-French

344 hatcheries are located in areas outside of Ireland which were not previously infected with

345 OsHV-1 $\mu$ var. Prior exposure can lead to latency (Dégremont et al., 2013), a common feature 346 of other herpesvirus infections (Arzul et al., 2002), and OsHV-1 $\mu$ var has been identified in 
347

348

349

350

351

352

353

354

355

356

357

358

359

360

361

362

363

364

365

366

367

368

369

370

apparently healthy oysters (Arzul et al., 2002; Barbosa-Solomieu et al., 2004; Dégremont et al., 2013). However, prior exposure will not result in a specific immune response, noting that molluscs lack immunological memory, relying entirely on innate immunity to overcome diseases (Gestal et al., 2008; Renault, 2008). Rather, the protective effect of prior exposure is likely genetic (Dégremont et al., 2007; Sauvage et al., 2009; Huvet et al., 2010), with oysters surviving a mortality event being naturally selected for resistance to disease (Dégremont et al., 2010; Pernet et al., 2012). In recent years, considerable progress has been made in France towards selection for OsHV-1 $\mu$ var resistant oysters, particularly in the context of summer mortality in adults (Dégremont et al., 2010; Dégremont et al., 2013). The second difference between the seed stocks relates to ploidy: a substantial proportion of the French-derived batches in this study were triploid $(88 \%)$, whereas most of the non-French-derived batches were diploid (75\%). In the current study, there was a univariable association between ploidy and cumulative batch mortality (with diploid stock being at greater risk, Table 3), however, ploidy was not retained in the final multivariable model (Table 4). This result is at odds with an earlier Irish study, where triploid oysters were at greater mortality risk (Peeler et al., 2012), but consistent with studies on adults from France, prior to 2006 at least (Gagnaire et al., 2006; Samain, 2011), which found triploid oysters were more resistant to summer mortality. This latter effect varied by season (Pernet et al., 2012), possibly due to seasonal differences in reproductive effort and immunological parameters. Given the data available, it is not possible to disentangle the relative importance of ploidy and prior OsHV-1 $\mu$ var exposure in the current study. The association with ploidy could be a consequence of confounding, noting that most of the French seed was triploid and most of the seed imported from non-French hatcheries was diploid. The observed effect could be due to innate resistance among stock from French hatcheries to OsHV-1 $\mu$ var infection. 
371 There was also some variation in the mortality of batches from different French hatcheries,

372 with median mortality varying between $7 \%$ and $25 \%$ (Table 3 ), although the sample size was

373 too small to conduct a formal analysis as to whether these differences in mortality were

374 significant. In these hatcheries, diploid females are produced locally, whereas the male

375 tetraploids are owned by the French government but moved from one hatchery to another for

376 the purposes of fertilization. This may reflect a degree of genetic selection in specific

377 hatcheries over the period since 2007/08 when the disease first appeared in France. A genetic

378 component, leading to hatchery differences, has previously been noted for summer mortality

379 in C. gigas adult oysters (Dégremont et al., 2007; Sauvage et al., 2009; Huvet et al., 2010).

380

381 In this study, the OsHV-1 $\mu$ var status of the bay was significantly associated with mortality,

382 (median mortality of $20 \%$ and $10 \%$ among bays where OsHV-1 $\mu$ var was detected, or not,

383 during 2011, respectively, Table 3). In this context, bay status is best interpreted in terms of

384 viral load during 2011, as opposed to either presence or absence, noting that we used a

385 sampling strategy to provide $95 \%$ confidence that virus would be detected, if present at a

386 specified design prevalence of $10 \%$ or greater (Table 1). Each of the 17 study bays can be

387 considered endemically infected: OsHV-1 $\mu$ var had been detected in each, either during 2011

388 or previously, and the virus is known to persist in adult oysters following primary infection

389 (Lipart and Renault, 2002; Dégremont et al., 2013). These observations are consistent with

390 earlier work, highlighting increased mortality risk with increasing quantities of OsHV-1 $\mu$ var

391 DNA, but frequently in the context of summer mortality in adults (Pepin et al., 2008; Sauvage

392

et al., 2009; Schikorski et al., 2011; Garcia et al., 2011).

393

394 We found a quadratic relationship between the natural logarithm of the cumulative mortality

395 and the maximum temperature observed between June and August 2011, noting that the 
maximum temperature observed in this study may have occurred as a one day event rather

397 than a sustained rise in temperature. In addition, for the seven high mortality sites at which

398

399

400

401

402

403

404

405

406

407

408

409

410

411

412

413

414

416

417

418

419

420

mortality date and temperature data were available, temperature had exceeded $16^{\circ} \mathrm{C}$ in the week prior to mortalities at five of the sites. At the other 2 sites, temperatures had either exceeded $16^{\circ} \mathrm{C}$ in the previous month (Sherkin) or were around $16^{\circ} \mathrm{C}$ in the previous week (Woodstown Strand) (Appendix B). However, there was little difference in the average temperature in the time prior to the mortalities when compared to sites with low mortalities (Table 2). A number of studies have highlighted the multifactorial nature of mortality events in oyster spat and larvae, with the European Food Safety Authority (EFSA, 2010) stating that climatic factors were unlikely to be a sufficient cause for summer mortalities. However, this publication also noted the absence of mortality outbreaks when the water temperature had been below $16^{\circ} \mathrm{C}$. Several authors have highlighted the potential role of increased water temperature in oyster mortality events. During 1998 to 2006 in France, OsHV-1 was often detected when temperatures increased quickly, but was no longer detected once temperatures were stable even if they remained high (Garcia et al., 2011). Further, a temperature increase may lead to a re-activation of latent infection (Sauvage et al., 2009). According to data collected from M1-M5 Databuoys deployed around the Irish coast, water temperatures were significantly lower in 2011 than in previous years (Marine Institute, http://www.marine.ie/home/publicationsdata/data/buoys/). Although several authors have highlighted the role of farm management (Samain and McCombie, 2010; European Food Safety Authority, 2010), no relevant variables were significant in the current multivariable modelling.

There are a number of limitations to the current study which we note here. We were reliant on farmer recall to determine the start date of mortalities. This proved problematic, however, 
421 both in terms of data validity and completeness. Further, the precision of these estimates is

422 influenced by the frequency with which farmers check their stock. In most cases, due to tidal

423 patterns which lead to site inaccessibility, stock can only be checked at best every two weeks,

424 and in some cases stock may not be checked for up to a month. Similar challenges have been

425 described previously among French oyster farmers, where yearly variation in reporting

426 sensitivity has been observed. Increases in reporting sensitivity were found to occur

427 concurrent with outbreak occurrence and with implementation of financial incentives to

428 encourage farmer reporting of mortality events (Lupo et al., 2012). The cumulative mortality

429 estimate for each batch in the study was based on the outcome of grading for each batch in

430 early spring 2012. Some farmers with several study batches found it difficult to obtain

431 grading data for individual batches as grading would usually be carried out on a stock basis

432 rather than a batch basis. We also faced some gaps in the environmental data, noting that

433 recordings were not taken during the same time period across all sites. In addition, although

434 data were available on a range of environmental parameters, only the temperature data proved

435 suitable for subsequent analysis. Extra environmental data were only recorded at a limited

436 number of sites due to cost and availability of monitoring equipment. There were some issues

437 with tracking batches once they had been split. Several batches were split during the season,

438 resulting in new stocking densities with new bag mesh sizes, and several new locations for

439 the split batch. This proved problematic when tracking split batches through the season, as

440 once the original batch was split, all subsequent batches had a separate set of data, and were

441 essentially a new batch. Initial sample size calculations were based on the difference in the

442 proportion of mortality in two groups. However, for the analysis linear regression with

443 cumulative mortality as the outcome was used. If sample size calculations had been based on

444 the difference between two mortality rates as described by Lwanga and Lemeshow (1990)

445 there would have been very little difference in the estimated sample size. Finally, the farms 
and study batches were not chosen at random, primarily for logistical reasons. It is possible

447 that these samples are not representative of the broader oyster farming population in Ireland.

448

449 The study provides some insights into mortality events affecting farmed Pacific oyster 450 production in Ireland. Batch mortality was lower in 2011, compared with earlier years, in

451 association with lower viral loads. Mortality was significantly associated with hatchery

452 source, for reasons that are currently unclear, and with water temperature. Further work is

453 needed to elucidate the basis for this effect. The relative importance of prior OsHV-1 $\mu$ var

454 infection and ploidy will become clearer with ongoing selection towards OsHV-1 $\mu$ var

455 resistant oysters. Work is currently underway in Ireland to investigate these factors further,

456 by tracking seed from various hatchery sources which were put to sea in 2012 under similar

457 husbandry and environmental conditions.

458

459

Acknowledgements

460

461 We gratefully acknowledge the assistance of participating oyster farmers, data collection by

462 Bord Iascaigh Mhara inspectors and Marine Institute staff and assistance from Dan Collins

463 (UCD Centre for Veterinary Epidemiology and Risk Analysis) with mapping.

464

465 Conflicts of interest

466 The authors do not have any conflict of interest.

467

468 Appendices A and B. Supplementary data

469 Supplementary data associated with this article can be found, in the online version.

470 
References

472

473 Arzul, I., Nicolas, J.L., Davison, A.J., Renault, T., 2001a. French Scallops: A New Host for

474 Ostreid Herpesvirus-1. Virology 290, 342-349.

475

476

Arzul, I., Renault, T., Lipart, C., Davison, A.J., 2001b. Evidence for interspecies transmission

477 of oyster herpesvirus in marine bivalves. J. Gen. Virol. 82, 865-870.

478

479

Arzul, I., Renault, T., Thébault, A., Gérard, A., 2002. Detection of oyster herpesvirus DNA

480

and proteins in asymptomatic Crassostrea gigas adults. Virus Res. 84, 151-160.

481

482

Barbosa-Solomieu, V., Miossec, L., Vázquez-Juárez, R., Ascencio-Valle, F., Renault, T.,

2004. Diagnosis of ostreid herpesvirus 1 in fixed paraffin-embedded archival samples using

PCR and in situ hybridisation. J. Virol. Methods 119, 65-72.

485

486

Batista, F.M., Arzul, I., Pepin, JF., Ruano, F., Friedman, C.S., Boudry, P., Renault, T., 2007.

487

Detection of ostreid herpesvirus 1 DNA by PCR in bivalve molluscs: A critical review. J.

488

Virol. Methods 139, 1-11.

489

490

Cohen, J., Cohen, P., West, S.G., Aiken, L.S., 2003. Applied multiple regression/correlation

491 analysis for the behavioural sciences. Third Edition. Routledge, New York, USA.

492

493 Dégremont, L., Boudry, P., Ropert, M., Samain, JF., Bédier, E., Soletchnik, P., 2010. Effects

494 of age and environment on survival of summer mortality by two selected groups of the

495 Pacific oyster Crassostrea gigas. Aquaculture 299, 44-50. 
497 Dégremont, L., D., Guyader, T., Tourbiez, D., Pepin, JF., 2013. Is horizontal transmission of 498 the ostreid herpesvirus OsHV-1 in Crassostrea gigas affected by unselected or selected

499 survival status in adults to juveniles? Aquaculture [doi: 10.1016/j.aquaculture.2013.05.025]

500

501 Dohoo, I., Martin, W., Stryhm, H., 2009. Veterinary Epidemiologic Research 2nd Edition.

502 VER Inc., Charlottetown, PEI, Canada.

503

504 European Community, 2010. 2010/221/EU: Commission decision of 15 April 2010

505

approving national measures for limiting the impact of certain diseases in aquaculture

506

animals and wild aquatic animals in accordance with Article 43 of Council Directive

507

2006/88/EC. Official Journal of the European Communities L98:7-11. 20 April 2010

508 [including subsequent amendments].

509

510 European Food Safety Authority, 2010. Scientific opinion on the increased mortality events

511 in Pacific oysters, Crassostrea gigas. EFSA J. 8, 1894.

512

513 Gagnaire, B., Soletchnik, P., Madec, P., Geairon, P., Le Moine, O., Renault, T., 2006.

514 Diploid and triploid Pacific oysters, Crassostrea gigas (Thunberg), reared at two heights

515 above sediment in Marennes-Oleron Basin, France: difference in mortality, sexual maturation 516 and hemocyte parameters. Aquaculture 254, 606-616.

517

518 Garcia, C., Thébault, A., Dégremont, L., Arzul, I., Miossec, L., Robert, M., Chollet, B.,

519 François, C., Joly, J.P., Ferrand, S., Kerdudou, N., Renault, T., 2011. Ostreid herpesvirus 1 
520 detection and relationship with Crassostrea gigas spat mortality in France between 1998 and 521 2006. Vet. Res. 42, 73.

522

523 Gestal, C., Roch, P., Renault, T., Pallavicini, A., Paillard, C., Novoa, B., Oubella, R., Venier, 524 P., Figueras, A., 2008. Study of diseases and the immune system of bivalves using molecular 525 biology and genomics. Rev. Fish. Sci. 16, 133-156.

526

527 Huvet, A., Normand, J., Fleury, E., Quillien, V., Fabioux, C., Boudry, P., 2010. Reproductive 528 effort of Pacific oysters: A trait associated with susceptibility to summer mortality. 529 Aquaculture 304, 95-99.

530

531 Lipart, C., Renault, T., 2002. Herpes-like virus detection in infected Crassostrea gigas spat 532 using DIG-labelled probes. J. Virol. Methods 101, 1-10.

533

534 Lupo, C., Osta, A.A., Mandard Y.V., Peroz C., Arzul, I., Francois, C., Garcia, C., Renault, T., 535 2012. Sensitivity of mortality reporting by the French oyster farmers. 13th Conference of the 536 International Symposium on Veterinary Epidemiology and Economics (ISVEE XIII), 20-24

537 August 2012, Maastricht, the Netherlands. http://archimer.ifremer.fr/doc/00102/21343/ 538

539 Lwanga, S.K., Lemeshow, S., 1991. Sample size determination in health studies. A practical 540 manual. World Health Organization, Geneva, Switzerland.

541

542 Malham, S.K., Cotter, E., O'Keeffe, S., Lynch, S., Culloty, S.C., King, J.W., Latchford, J.W., 543 Beaumont, A.R., 2009. Summer mortality of the Pacific oyster, Crassostrea gigas, in the 
544 Irish Sea: The influence of temperature and nutrients on health and survival. Aquaculture $545 \quad 287,128-138$.

546

547 Peeler, E.J., Reese, A., Thrush, M.A., 2010. Report on investigation of oyster herpes virus 548 infection and oyster mortality in the Republic of Ireland in 2009 - a questionnaire survey.

549 Centre for Environment, Fisheries \& Aquaculture Science (Cefas), Weymouth, UK. July 5502010.

551

552 Peeler, E.J., Reese, R.A., Cheslett, D.L., Geoghegan, F., Power, A., Thrush, M.A., 2012.

553 Investigation of mortality in Pacific oysters associated with ostreid herpesvirus-1 $\mu$ var in the 554 Republic of Ireland in 2009. Prev. Vet. Med. 105, 136-143.

555

556 Pepin, J.F., Riou, A, Renault, T., 2008. Rapid and sensitive detection of ostreid herpesvirus 1 557 in oyster samples by real-time PCR. J. Virol. Methods. 149, 269-76.

558

559

Pernet, F., Barret, J., Le Gall, P., Corporeau, C., Dégremont, L., Lagarde, F., Pepin, J.F., 560

Keck, N., 2012. Mass mortalities of Pacific oysters Crassostrea gigas reflect infectious

561 diseases and vary with farming practices in the Mediterranean Thau lagoon, France.

562 Aquacult. Environ. Interact. 2, 215-237.

563

564 Renault, T., Arzul, I., 2001. Herpes-like virus infections in hatchery-reared bivalve larvae in

565 Europe: specific viral DNA detection by PCR. J. Fish Dis. 24, 161-167.

566

567 Renault, T.C., 2008. Genomics and mollusc pathogens: trends and perspective. J. Vet. Clin.

568 Sci. $1,36-46$. 
570 Samain, J.F., McCombie, H. (eds), 2010. Summer mortality of Pacific oyster Crassostrea

571 gigas. The Morest project. Éditions Quæ.

572

573 Samain, J.F., 2011. Review and perspectives of physiological mechanisms underlying

574 genetically-based resistance of the Pacific oyster Crassostrea gigas to summer mortality.

575 Aquat. Living Resour. 24, 227-236.

576

577 Sauvage, C., Pepin, J.-F., Lapègue, S., Boudry, P., Renault, T., 2009. Ostreid herpes virus 1

578 infection in families of the Pacific oyster, Crassostrea gigas, during a summer mortality

579 outbreak: Differences in viral DNA detection and quantification using real-time PCR. Virus

580 Res. $142,181-187$.

581

582 Schikorski, D., Renault, T., Saulnier, D., Faury, N., Moreau, P., Pepin, JF., 2011.

583 Experimental infection of Pacific oyster Crassostrea gigas spat by ostreid herpesvirus 1:

584 demonstration of oyster spat susceptibility. Vet. Res. 42, 27.

585

586 Segarra, A., Pepin, JF., Arzul, I., Morga, B., Faury, N., Renault, T., 2010. Detection and

587 description of a particular Ostreid herpesvirus 1 genotype associated with massive mortality

588 outbreaks of Pacific oysters, Crassostrea gigas, in France in 2008. Virus Res. 153, 92-99.

589

590 Tidwell, J. H., 2012. Aquaculture Production Systems. Wiley-Blackwell, Oxford, UK.

591

592 Tables:

593 
594 Table 1. Independent variables considered in the study

595

596 Table 2. The median and interquartile range of temperature recorded within 7 and 30 days of

597 the reported start of mortalities at seven high mortality sites (those with 1 or more batches

598 with a cumulative mortality $>34 \%$ ) during summer 2011 in Ireland. The median and

599 interquartile range of temperatures at the ten low mortality sites (those sites without any high

600 mortality batches) during the same time periods is included for comparison.

601

602 Table 3. The median cumulative mortality of oyster batches in Ireland in 2011, along with the 603 interquartile range by categorical risk factors that met the criteria for inclusion in the

604 multivariable model $(\mathrm{p}<0.2)$.

605

606 Table 4. Linear mixed regression model of the log of batch mortality among 80 batches of 607 oysters in Ireland in 2011

608

609 Figures:

610

611 Figure 1. The location of study batches and environmental data loggers (Hydrolab DS5

612 Multiparameter Datasonde loggers;_CTD loggers (DGS - Dungarvan South and DGN -

613 Dungarvan North); RCM9 loggers) in Dungarvan Bay during 2011-12

614

615 Figure 2. Location of the 80 study batches and 17 bays, and the cumulative batch mortality

616 (average, range) in each bay, of farmed C. gigas in Ireland during summer 2011

617 
618 Figure 3. Distribution of the cumulative mortality (\%) among the 80 study batches in Ireland 619 during summer 2011

620

621 Figure 4. Predicted best linear unbiased estimator of the cumulative mortality from the

622 multivariable mixed linear model plotted against the maximum summer temperature, for each

623 hatchery in OsHV-1 $\mu$ var positive bays

624 
624 Table 1. Independent variables considered in the study

625

\begin{tabular}{|c|c|}
\hline Independent variable & Explanation \\
\hline Time in water & $\begin{array}{l}\text { Measured in days from date of immersion until date of final batch } \\
\text { grading. Also grouped into time when placed in water (2010, } \\
\text { Spring } 2011 \text { and Summer 2011) }\end{array}$ \\
\hline Age placed in water & $2-3,4-7,>7$ (months) \\
\hline Ploidy & Diploid, triploid \\
\hline Bay & 17 bays \\
\hline Position on shore & Low, mid, high \\
\hline $\begin{array}{l}\text { OsHV-1 } \mu \text { var bay } \\
\text { status }^{\mathrm{a}}\end{array}$ & OsHV-1 $\mu$ var detection in 2011 (positive/negative) \\
\hline Bag turning & Number of times each bag turned between May to August 2011 \\
\hline Transport & Air, sea and road, road \\
\hline Journey duration & $\leq 24 \mathrm{hrs},>24$ and $<36 \mathrm{hrs}, \geq 36 \mathrm{hrs}$ and $<42 \mathrm{hrs}, \geq 42 \mathrm{hrs}$ \\
\hline Bag mesh size & $<4,4$ and $>4(\mathrm{~mm})$ \\
\hline Hatchery & The 7 hatcheries from which the oysters originated \\
\hline Handling at grading & Manual, mechanical, both \\
\hline Sea bed type & Gravel, gravel/sand, mud, mud/sand, sand \\
\hline Average stocking & Average no. of oysters per bag. If bags were split, oyster density \\
\hline density & was as estimated at the end of May 2011 \\
\hline Bag split & $\begin{array}{l}\text { Whether bags were split during the study into smaller number of } \\
\text { oysters (Yes/No) }\end{array}$ \\
\hline $\begin{array}{l}\text { Maximum summer } \\
\text { temperature }\end{array}$ & $\begin{array}{l}\text { Maximum temperature reached from the start of June until the end } \\
\text { of August 2011, measured at } 23 \text { sites with between } 1 \text { and } 8 \text { batches }\end{array}$ \\
\hline
\end{tabular}


at each site.

626 a. Sampling was carried out on a bay basis (i.e. 30 animals from one batch in each bay was

627 sampled for the presence of OsHV-1, the sample size was based on detecting a design

628 prevalence of $10 \%$ or greater with $95 \%$ confidence), however, the batch sampled may not

629 have been part of this study. A bay was considered positive if at least one batch was infected. 
630

Table 2. The median and interquartile range of temperature recorded within 7 and 30 days of the reported start of mortalities at seven high mortality sites (those with 1 or more batches with a cumulative mortality $>34 \%$ ) during summer 2011 in Ireland. The median and interquartile range of temperatures at the ten low mortality sites (those sites without any high mortality batches) during the same time periods is included for comparison

At each high mortality site

\begin{tabular}{ll}
\hline Bay $^{\mathrm{a}}$ & Reported statt \\
& \\
\hline Within 7 days of start of mortalities \\
Achill Sound & 14-Jul-11 \\
Clew Bay & 20-Jul-11 \\
Dungloe & 03-Jul-11 \\
Lough Swilly & 22-Jul-11 \\
Sherkin & 11-Aug-11 \\
Trawbreaga Bay & 26-Jul-11 \\
Woodstown Strand & 26-Jul-11
\end{tabular}

Among the ten low mortality sites ${ }^{\mathrm{a}}$

\begin{tabular}{llc}
\hline \multicolumn{2}{c}{ Temperature } \\
\hline \multirow{2}{*}{ Median } & \multicolumn{2}{c}{ interquartile range } \\
\cline { 2 - 3 } & Q1 $\quad$ Q3
\end{tabular}

\section{Temperature

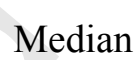

Q1

$\begin{array}{rrrrrr}15.9 & 14.9 & 16.7 & 15.3 & 14.5 & 16.5 \\ 14.8 & 13.9 & 15.8 & 15.0 & 13.7 & 16.7 \\ 15.7 & 15.3 & 16.9 & 14.4 & 13.5 & 15.7 \\ 18.8 & 15.5 & 20.0 & 14.4 & 13.4 & 15.4 \\ 14.8 & 14.5 & 15.1 & 15.9 & 15.4 & 16.3 \\ 15.2 & 14.4 & 16.9 & 14.9 & 14.1 & 16.1 \\ 14.8 & 14.4 & 15.6 & 14.9 & 14.1 & 16.1\end{array}$


Within 30 days of start of mortalities

$\begin{array}{llcccccc}\text { Achill Sound } & \text { 14-Jul-11 } & 17.0 & 15.6 & 18.8 & 19.2 & 18.0 & 19.8 \\ \text { Clew Bay } & \text { 20-Jul-11 } & 15.0 & 14.2 & 15.8 & 15.3 & 14.0 & 18.5 \\ \text { Dungloe } & \text { 03-Jul-11 } & 15.5 & 15.0 & 16.2 & 19.3 & 18.4 & 19.9 \\ \text { Lough Swilly } & \text { 22-Jul-11 } & 20.5 & 17.4 & 22.9 & 14.8 & 13.7 & 16.0 \\ \text { Sherkin } & \text { 11-Aug-11 } & 14.5 & 13.7 & 14.9 & 15.8 & 14.8 & 16.5 \\ \text { Trawbreaga Bay } & \text { 26-Jul-11 } & 15.2 & 14.3 & 16.3 & 15.0 & 14.0 & 16.3 \\ \text { Woodstown Strand } & \text { 26-Jul-11 } & 15.1 & 14.6 & 15.7 & 15.0 & 14.0 & 16.3 \\ \end{array}$

a. The bay may also contain other sites 
635 Table 3. The median cumulative mortality of oyster batches in Ireland in 2011, along with the

636 interquartile range by categorical risk factors that met the criteria for inclusion in the

637 multivariable model $(\mathrm{p}<0.2)$

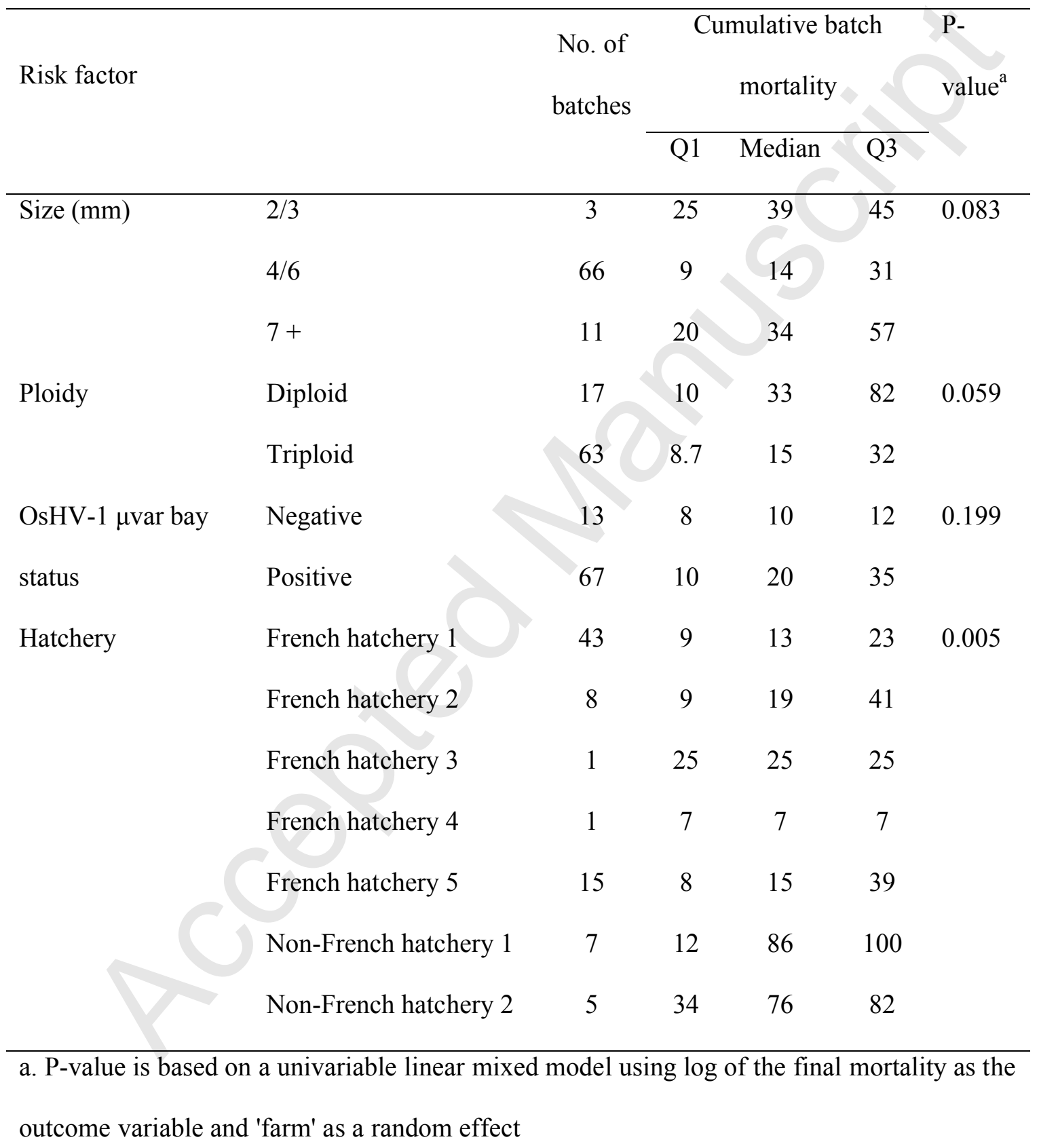


640 Table 4. Linear mixed regression model of the log of batch mortality among 80 batches of

641 oysters in Ireland in 2011

\begin{tabular}{|c|c|c|c|c|}
\hline \multirow[b]{2}{*}{ Variable } & \multirow[b]{2}{*}{ Categories } & \multicolumn{3}{|c|}{ Standard } \\
\hline & & Estimate & error & $P$ value \\
\hline Intercept & & 4.57 & 0.47 & $<0.001$ \\
\hline \multirow[t]{7}{*}{ Hatchery } & French hatchery 1 & -1.73 & 0.46 & $<0.001$ \\
\hline & French hatchery 2 & -1.37 & 0.52 & 0.010 \\
\hline & French hatchery 3 & -1.20 & 0.84 & 0.157 \\
\hline & French hatchery 4 & -1.97 & 0.87 & 0.026 \\
\hline & French hatchery 5 & -1.33 & 0.50 & 0.011 \\
\hline & Non-French hatchery 1 & -0.01 & 0.53 & 0.982 \\
\hline & Non-French hatchery 2 & 0.00 & . & . \\
\hline \multirow[t]{2}{*}{ OsHV-1 $\mu$ var bay status } & Negative & -0.85 & 0.37 & 0.035 \\
\hline & Positive & 0.00 & . & . \\
\hline Max. summer temp & & 0.05 & 0.03 & 0.116 \\
\hline Max. summer temp ${ }^{2}$ & & -0.01 & 0.005 & 0.040 \\
\hline \multirow{2}{*}{ Random effects } & & Variance & Standard & \\
\hline & & estimate & error & \\
\hline Farm & & 0.270 & 0.160 & \\
\hline Residual & & 0.443 & 0.095 & \\
\hline
\end{tabular}

642

643 
1 Figure 1. The location of study batches and environmental data loggers (Hydrolab DS5

2 Multiparameter Datasonde loggers, _CTD loggers (DGS - Dungarvan South \& DGN -

3 Dungarvan North); RCM9 loggers) in Dungarvan Bay during 2011-12

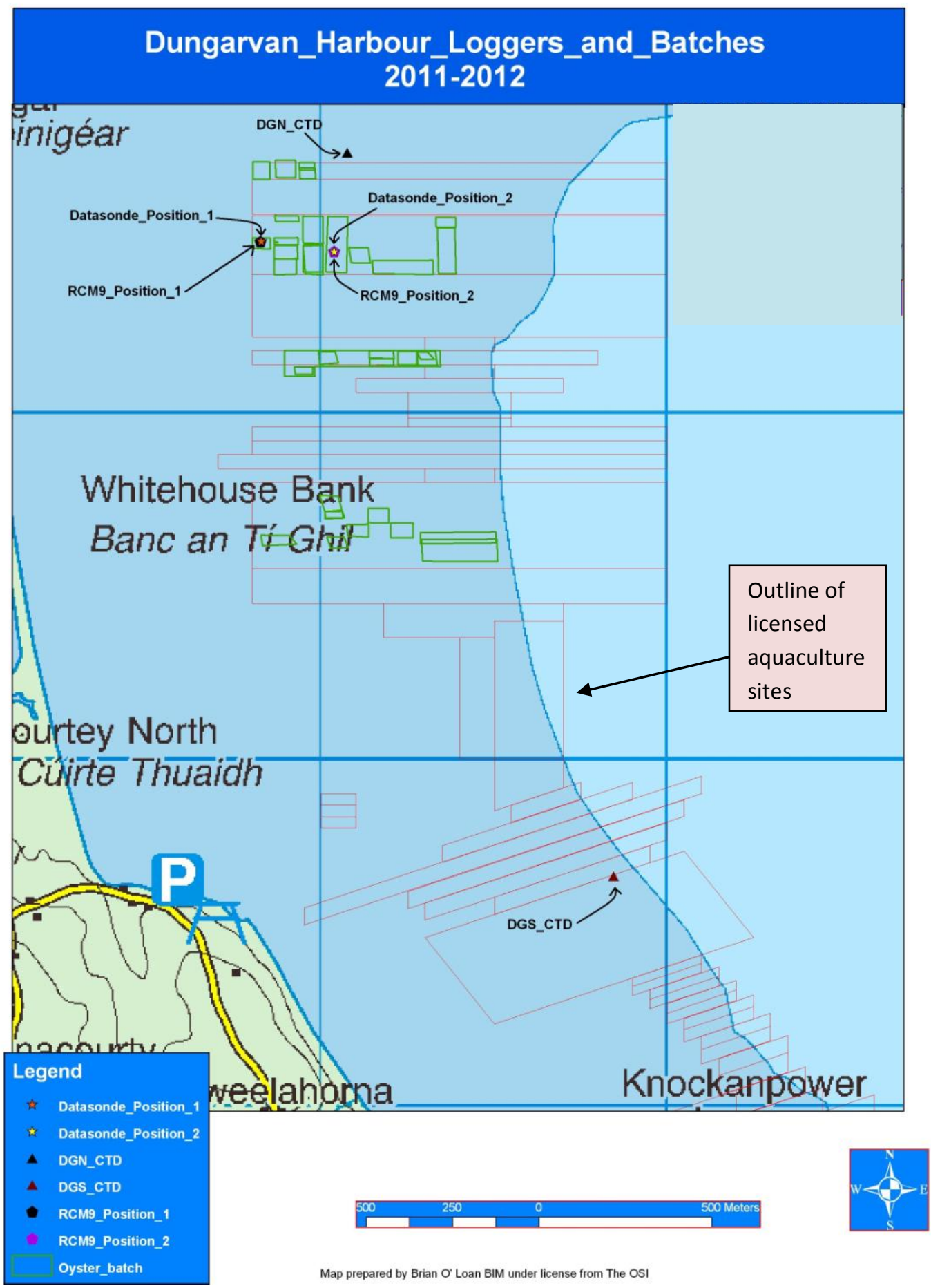


6 Figure 2. Location of the 80 study batches and 17 bays, and the cumulative batch mortality

7 (average, range) in each bay, of farmed Crassostrea gigas in Ireland during summer 2011

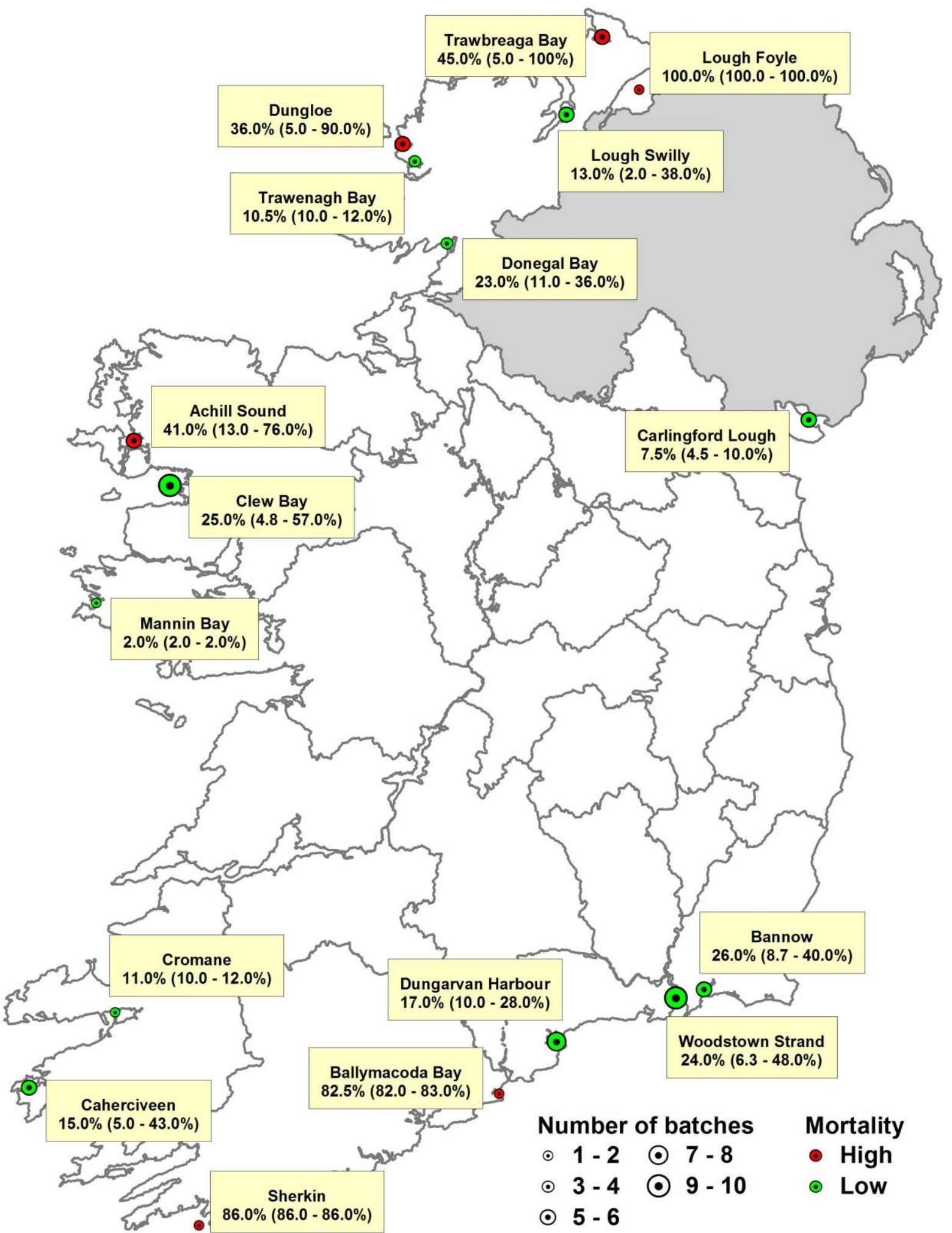

$\bigwedge 50 \quad 0050$ 
9 Figure 3. Distribution of the cumulative mortality (\%) among the 80 study batches in Ireland

10 during summer 2011

11

12

13

14

15

16

17

18

19

20

21

22

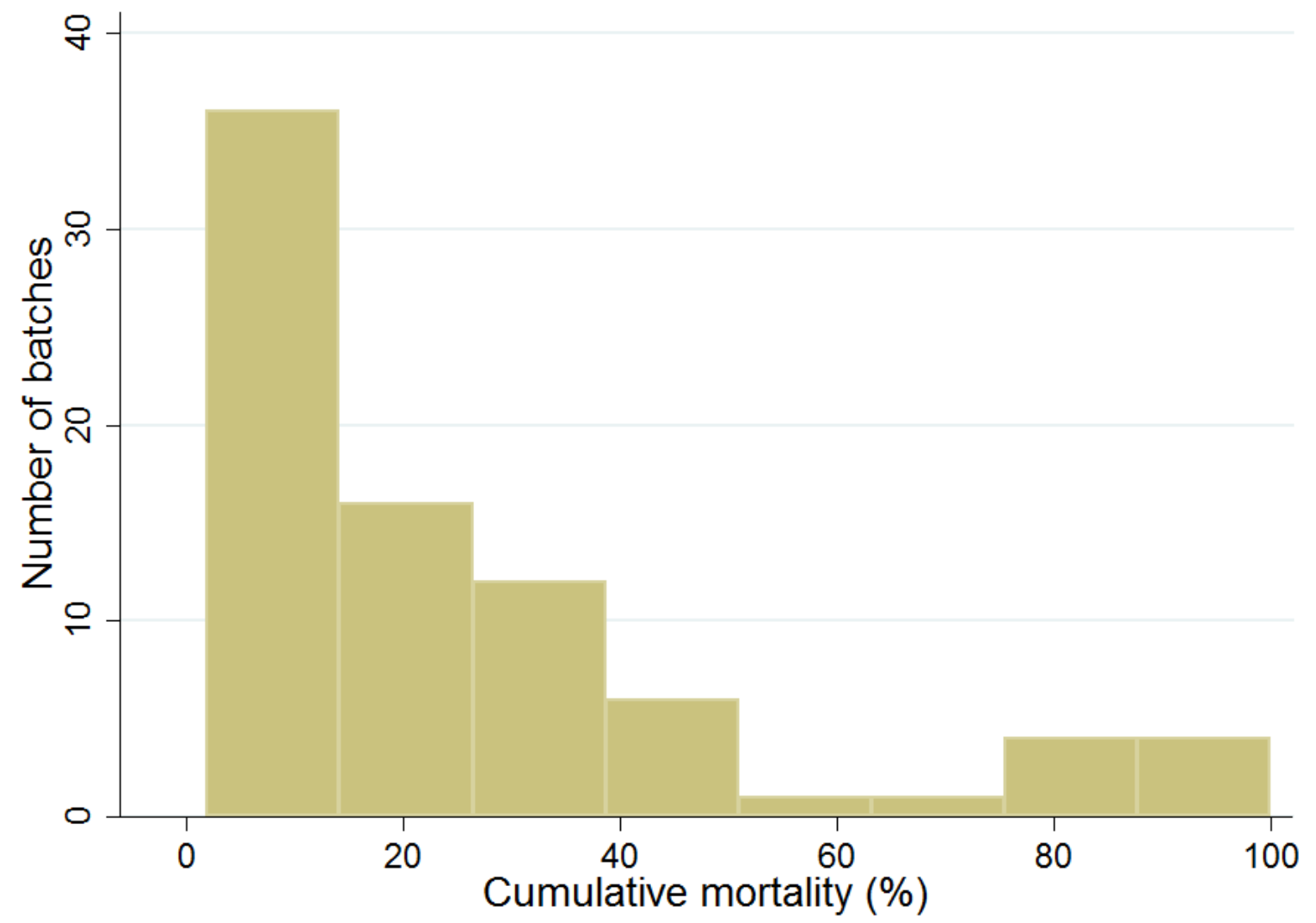

23 
Figure 4. Predicted best linear unbiased estimator of the cumulative mortality from the multivariable mixed linear model plotted against the maximum summer temperature, for each hatchery in OsHV-1 $\mu$ var positive bays

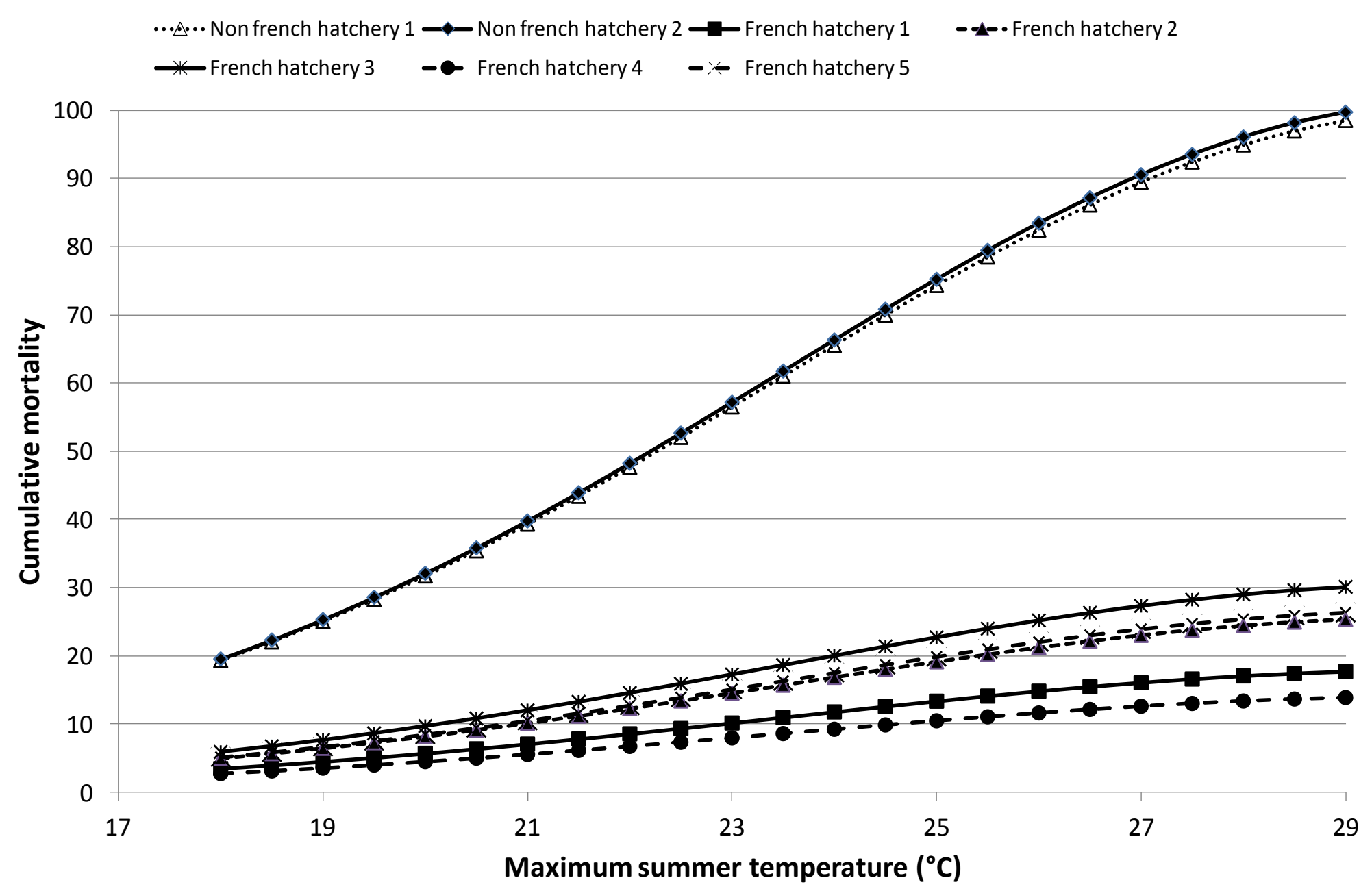

